\title{
A Rare Northern Pacific Item
}

A Northern Pacific item of great rarity and value will be added to the Library files when the business collection of the Boston Public Library comes into the keeping of the Business Library. This pamphlet, a "Partial report . . . of a reconnoissance made in the summer of 1869 , between Lake Superior and the Pacific Ocean, by Thos. Hawley Canfield, general agent of the company, accompanied with notes on Puget Sound by Samuel Wilkeson, Esq., the historian of the expedition," recently changed hands for $\$ 150$ at an auction.

When Jay Cooke took over the financing of the Northern Pacific Railroad, he organized a party to explore the line of the proposed road, going west over the Union and Central Pacific roads, thence north by steamer and stage to Puget Sound, and back through the country to be traversed by the Northern Pacific. Among other things, the party was to investigate, with a view to fixing the northwestern terminus of the railroad, the several considerable settlements around Puget Sound. Canfield's report includes correspondence from various local men, familiar with the country, on whom, because of the shortness of his stay, he was dependent for most of his information. These ardent patriots set forth in equally glowing terms the reasons why the east, or west, side of the Sound, Bellingham Bay, Port Townsend, or Seattle, as the case may be, is indisputably the spot for terminating the new line; and Samuel Wilkeson, an ex-newspaper man, and recently elected secretary of the railroad company, adds his exuberant praises of the whole region. One quotation will suffice to show the predominant tone of enthusiasm. Wilkeson quotes from a Bellingham Bay partizan: "The climate here is unsurpassed. Sickness is almost unknown. In winter the south-east winds prevail, bringing the warm air of the south and rain, while in summer westerly winds prevail during the heat of the day, sweeping in the tonic sea-air of the Pacific, which dies away at sundown and is followed by the cool air from the eternal snows of Mount Baker. This enables the weary laborer to enjoy refreshing sleep under a pair of blankets during the hottest time of the year, while the inhabitants of the interior and Eastern States are panting for a breath of cool air.... Breathing such air and using such water as is here - springs cold as ice and clear as crystal - with temperate habits, in the absence of hereditary disease, sickness is impossible." 
It is evident from the foregoing quotation that the modern habit of "selling the climate" began early in the history of the Pacific coast.

\section{The Livery Companies of London}

THE mediaeval craft guild owing its origin to religion, and protected by the church, was a remarkable institution in its way, caring as it did, at least in its best days, for the well-being of its members while exacting from them a certain standard of workmanship. It is an arguable point that the worker of the Middle Ages, often engaged on creative tasks and deriving from his labor the satisfaction of his artistic instincts, was a happier man than the modern factory employee, whose work frequently consists in the continuous repetition of one monotonous operation. However that may be, there is no denying the picturesque element that attaches to the surviving guilds of London - the Livery Companies. These companies, which have long since divested themselves of their connection with their distinctive trades, and which the average person usually thinks of as organizations whose primary purpose is the providing of elegant banquets as opportunities for Guildhall speeches, are still tenacious of their municipal privileges, and in their existence perpetuate many phases of mediaeval municipal institutions.

The Society has recently acquired an attractive collection of the histories of the various Companies as well as several volumes dealing with them generally. The histories, mainly nineteenth-century works, include the Merchant Taylors, the Skinners, Drapers, Tallow-Chandlers, and other well-known Companies. So far, those of the Fishmongers, Haberdashers, Salters, and Vintners are lacking. It is aimed to complete the set.

Charles F. Heartman, at Metuchen, New Jersey, publishes a periodical most valuable to librarians, The Americana Collector. In its pages the reader explores all phases of the antique and the curious, from the letters of Carlyle to the superstitions current among the Pennsylvania Dutch. From a book on the latter comes a prescription for avoiding injuries: "Carry the right eye of a wolf fastened inside your right sleeve." 